\title{
Microbiology Specimen Date Time
}

National Cancer Institute

\section{Source}

National Cancer Institute. Microbiology Specimen Date Time. NCI Thesaurus. Code C88015.

The date and time of the microbiology specimen data. 